\title{
INTEGRATED FABRICATION OF A MICRO METHANOL REFORMER AND A HYDROGEN PEROXIDE HEAT SOURCE
}

\author{
Taegyu Kim and Sejin Kwon \\ Department of Aerospace Engineering, Korea Advanced Institute of Science and Technology \\ 373-1 Guseong-dong, Yuseong-gu, Daejeun, 305-701 Korea \\ Tel: +82-42-869-3721, Fax: +82-42-869-3710, E-mail: trumpet@kaist.ac.kr
}

\begin{abstract}
This paper presents the design, fabrication and evaluation of a micro methanol reformer complete with a heat source. The micro system consists of the steam reforming reactor of methanol, the catalytic decomposition reactor of hydrogen peroxide, and a heat exchanger between the two reactors. In the present study, catalytic decomposition of hydrogen peroxide is used as a process to supply heat to the reforming reactor. The fabrication process integrated with the catalyst loading process is developed. The performance of the methanol steam reforming system was measured at various test conditions and the optimum operation condition was sought.
\end{abstract}

\section{INTRODUCTION}

Recently, polymer electrolyte membrane fuel cell (PEMFC) has been renowned as a primary candidate to substitute existing batteries in mobile applications [1]. A major constraint in the successful development of micro scale PEMFC has been the difficulties and hazards involved in the storage and handling of hydrogen that is the fuel for this fuel cell [2]. A fuel reformer that can extract gaseous hydrogen from a hydrocarbon fuel is an essential subsystem for PEMFC. Due to the high storage density, liquid fuels are most attractive for mobile applications; methanol is considered to be a primary candidate [3]. There are a number of fuel reforming techniques available, such as steam reforming, partial oxidation and autothermal reforming [4]. Of all considered techniques, the steam reforming, expressed in the chemical equation (1), provides the highest attainable hydrogen concentration in the reformate gas. This reaction takes place at relatively low temperature in the range of $200-300{ }^{\circ} \mathrm{C}$ [3]. Consequently, the $\mathrm{CO}$ emission is relatively small, which can be eliminated by preferential oxidation (PROX) [4].

$\mathrm{CH}_{3} \mathrm{OH}(\mathrm{l})+\mathrm{H}_{2} \mathrm{O}(\mathrm{l}) \rightarrow 3 \mathrm{H}_{2}+\mathrm{CO}_{2}, \quad \Delta \mathrm{H}_{\mathrm{f}}^{\mathrm{o}}=131 \mathrm{~kJ} / \mathrm{mol}$

The steam reforming of methanol is endothermic reaction and requires continuous heat supply to the reactor. As a typical heating element of MEMS-based methanol reformer, a micro electric heater is the simplest method to heat up the reformer because its heat control is relatively easy and system integration with fabrication process using MEMS technologies are also simple. However, the crucial drawback of the electric heater is low thermal efficiency, so it has been used for a start-up heater. As another heating element, catalytic combustion has been attractive due to its high thermal efficiency. However, non-uniform distribution of temperature and hot spot formation in front of the combustor is still problematic.

In the present study, catalytic decomposition of hydrogen peroxide, expressed in the chemical equation (2), is used as a process to supply heat to the reforming reactor

$\mathrm{H}_{2} \mathrm{O}_{2}(\mathrm{l}) \rightarrow \mathrm{H}_{2} \mathrm{O}(\mathrm{l})+0.5 \mathrm{O}_{2}, \quad \Delta \mathrm{H}_{\mathrm{f}}^{\mathrm{o}}=-54.24 \mathrm{~kJ} / \mathrm{mol}$

The conceptual drawing of the hydrogen peroxide heat source is presented in Fig. 1. This decomposition

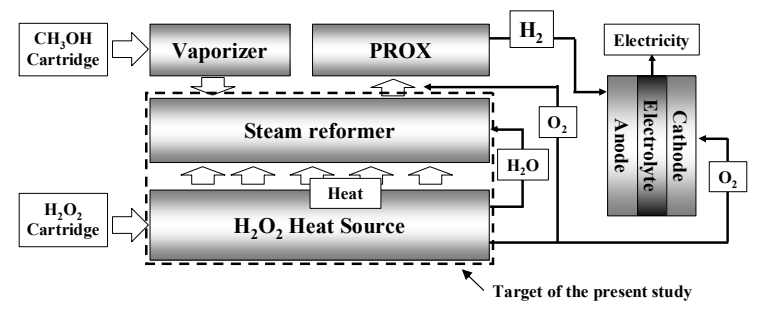

Fig. 1 System concept of integration of methanol steam reforming and hydrogen peroxide heat source 
reaction is highly exothermic enough to sustain the steam reforming of methanol and is high active and selective under various metal catalysts such as $\mathrm{Fe}, \mathrm{Cu}$, $\mathrm{Ni}, \mathrm{Cr}, \mathrm{Pt}, \mathrm{Pd}, \mathrm{Ir}, \mathrm{Mn}$ and so on. The decomposition process of hydrogen peroxide produces water vapor that can be recycled in the steam reforming of methanol and oxygen that can be used in preferential oxidation of $\mathrm{CO}$ and supplement the oxygen from ambient air at the cathode of the fuel cell stack. The present concept renders the system far more compact than the existing reformer/combustor model because hydrogen peroxide is stored and used in condensed phase and oxygen enrichment enhances the system efficiency.

This paper presents the design, fabrication and evaluation of a micro methanol reformer complete with a hydrogen peroxide heat source. Respective catalysts were prepared that loaded into porous ceramic support for methanol steam reforming and hydrogen peroxide decomposition. The integrated reforming system was fabricated that consists of the steam reforming reactor of methanol, the catalytic decomposition reactor of hydrogen peroxide, and a heat exchanger between the two reactors. The integrated performance was measured at various test conditions and optimum condition was sought.

\section{CATALYST}

$\mathrm{Cu} / \mathrm{ZnO}$ was selected as a catalyst for methanol steam reforming, considering its proven reactivity and selectivity [5]. In this catalyst, $\mathrm{Cu}^{0}$ provides the catalytic activity, while $\mathrm{ZnO}$ stabilizes the $\mathrm{Cu}$ surface area [5]. Pt was chosen as a catalyst for the decomposition process of hydrogen peroxide. Incipient wetness method was used to load both catalysts on a porous support that increases catalytic area. As a catalyst support, we used the porous ceramic material $\left(\right.$ ISOLITE $^{\circledR}$ ). This catalyst structure can enhance the heat and mass transport between the catalyst active site and the reactants.

\section{DESIGN}

Figure 2 depicts the system construction. The mixture of methanol and water enters at upper reforming reactor, converted into hydrogen and carbon dioxide under the $\mathrm{Cu} / \mathrm{ZnO}$ catalyst. The hydrogen peroxide
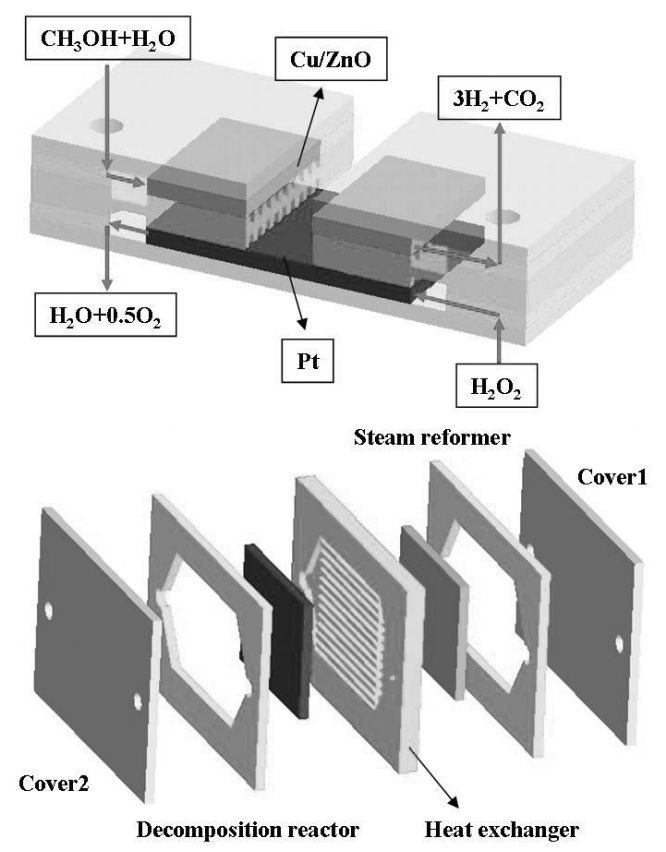

Fig. 2 System construction integrated with methanol reforming reactor unit and hydrogen peroxide decomposition reactor unit

flows into the decomposition reactor with countercurrent stream to the reforming reactor. The hydrogen peroxide is decomposed into the water vapor and oxygen under the Pt catalyst and the heat produced from decomposition reaction is transferred to the reforming reactor through the heat exchanger having straight micro-fins.

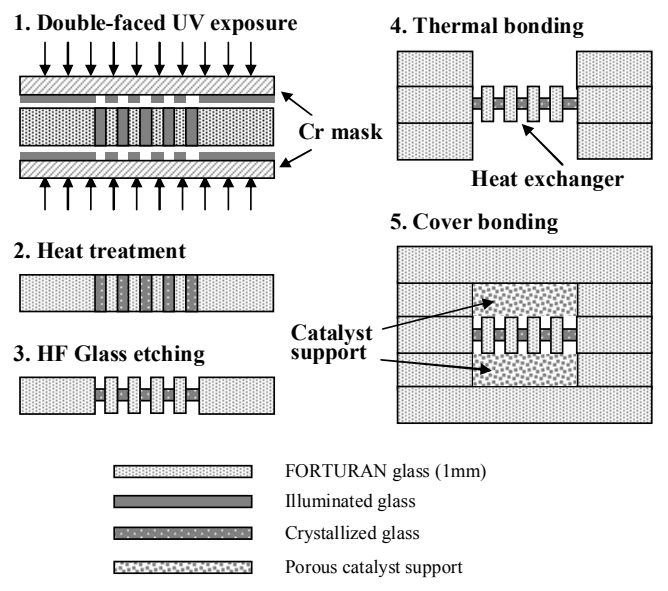

Fig. 3 Integrated fabrication procedure of the reforming reactor and the decomposition reactor 

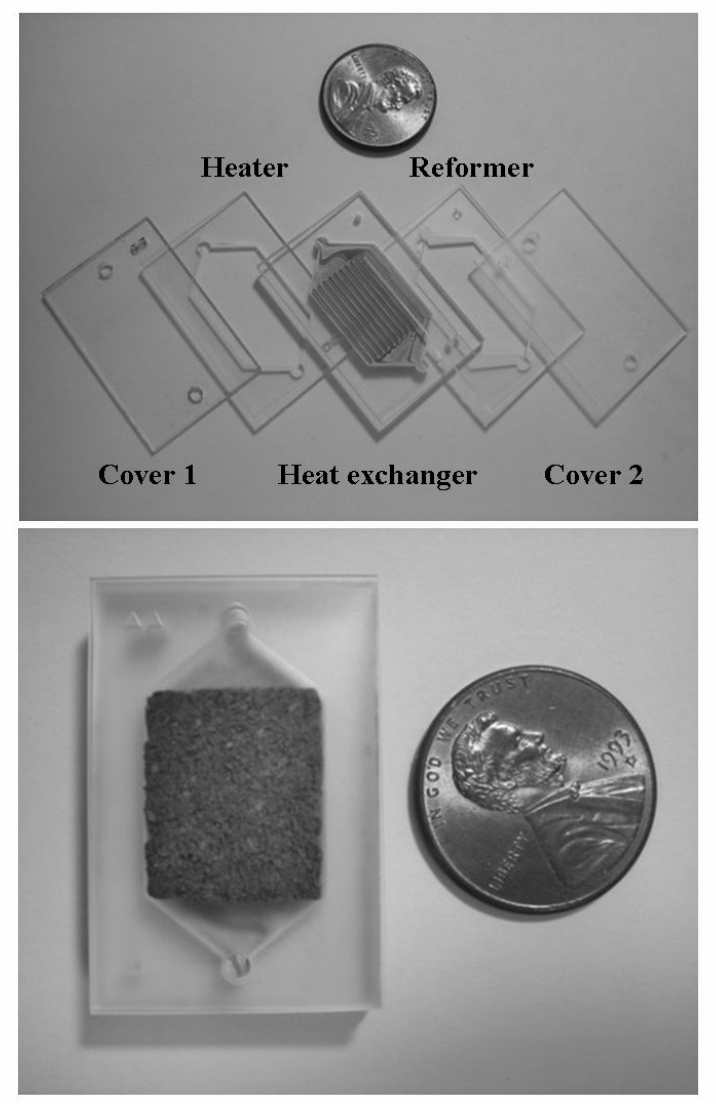

Fig. 4 Fabricated results; individual glass wafers (top), the complete integrated reforming system (bottom)

\section{FABRICATION}

The reactor structure was made of five glass wafers; two for top and bottom, one for reforming reactor unit, one for hydrogen peroxide decomposition reactor unit and the remaining for heat exchanger inbetween. The catalyst loaded supports were inserted in the cavity made on the glass wafer as in Fig. 3. A photosensitive glass wafer $\left(\right.$ FORTURN ${ }^{\circledR}$ ) was used for the substrate of the reactor unit. The wafer material is adequate as a material of microreactor because it has properties unique to glass such as transparency, hardness and chemical resistance and it is possible to achieve very fine structures with tight tolerances and high aspect ratio [5]. Fabrication process for individual glass wafer included; exposure to UV light under a mask at the intensity of $2 \mathrm{~J} / \mathrm{cm}^{2}$, heat treatment at $585{ }^{\circ} \mathrm{C}$ for $1 \mathrm{~h}$ to crystallize the part of the glass that was exposed to UV [5]. The exposed part was etched in the $10 \% \mathrm{HF}$ solution to result in

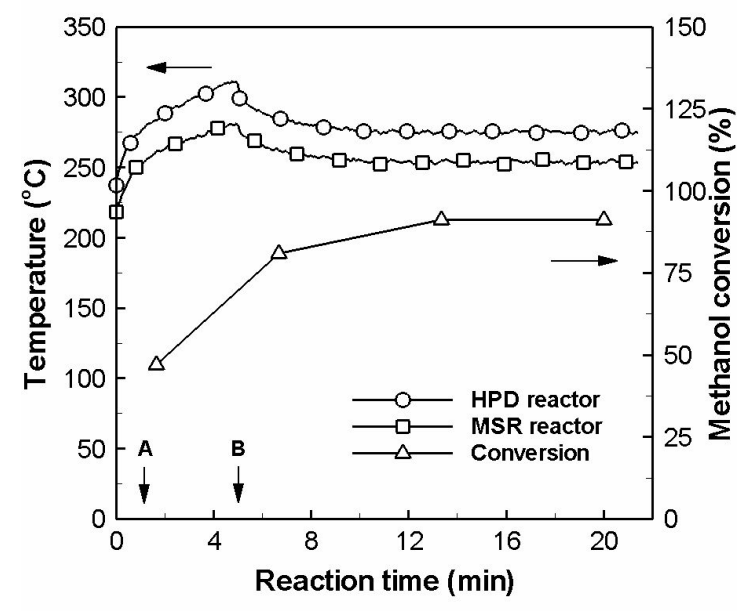

Fig. 5 Integrated operation of the methanol steam reformer and the hydrogen peroxide decomposition reactor (82 wt $\% \mathrm{H}_{2} \mathrm{O}_{2}, 9.48 \mathrm{~mol} / \mathrm{g}-\mathrm{h}, \mathrm{A}: \mathrm{CH}_{3} \mathrm{OH} 0.68$ $\left.\mathrm{mol} / \mathrm{g}-\mathrm{h}, \mathrm{S} / \mathrm{C}=1.1, \mathrm{~B}: \mathrm{H}_{2} \mathrm{O}_{2} 6.32 \mathrm{~mol} / \mathrm{g}-\mathrm{h}\right)$

the desired shape. The membrane thickness of heat exchanger was determined by control of etching time. The exposed part of the glass was removed during this process at a rate of $1 \mathrm{~mm}$ per hour. The fabrication process integrated with the catalyst loading process is illustrated in Fig. 3. Figure 4 shows the fabricated glass wafers and the complete reforming system obtained by fusion-bonding the fabricated glass layers. The bonding process involved pressing the layers together with pressure of 1000 $\mathrm{N} / \mathrm{m}^{2}$ in the furnace whose temperature was maintained at $500{ }^{\circ} \mathrm{C}[5]$.

\section{INTEGRATED PERFORMANCE}

Figure 5 represents the result of simultaneous operation of the methanol steam reformer and the hydrogen peroxide decomposition reactor. The reformer was heated up to $250{ }^{\circ} \mathrm{C}$ under the decomposition reactor with a space velocity of 9.48 $\mathrm{mol} / \mathrm{g}-\mathrm{h}$ and then a mixture of methanol and water was supplied to the reformer (figure 5 (A)). The space velocity of methanol was $0.68 \mathrm{~mol} / \mathrm{g}$-h. The temperature increased continuously though the steam reforming of methanol was started, it means an excessive hydrogen peroxide was supplied. So the flow rate of hydrogen peroxide was reduced to the space velocity of $6.32 \mathrm{~mol} / \mathrm{g}$-h after the operation lasted $5 \mathrm{~min}$ (figure 5 (B)). From $8 \mathrm{~min}$, the steady 


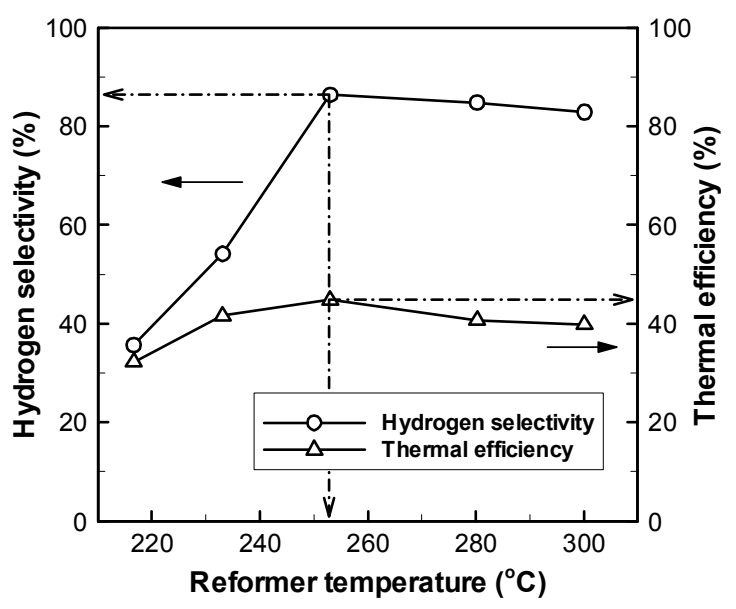

Fig. 6 Hydrogen selectivity and thermal efficiency as a function of reformer temperature $\left(\mathrm{CH}_{3} \mathrm{OH} \quad 0.68\right.$ $\mathrm{mol} / \mathrm{g}-\mathrm{h}, \mathrm{S} / \mathrm{C}=1.1,82 \mathrm{wt} \% \mathrm{H}_{2} \mathrm{O}_{2}$

reforming reaction was achieved with the conversion over $91.2 \%$ and then the temperature of the reformer and the decomposition reactor was 253 and $278{ }^{\circ} \mathrm{C}$, respectively.

Figure 6 shows the hydrogen selectivity and the thermal efficiency of the system as a function of reformer temperature. The hydrogen selectivity increased with the thermal efficiency as the reformer temperature increased. At the temperature higher than $250{ }^{\circ} \mathrm{C}$, however, the hydrogen selectivity decreased with the temperature because the production of the carbon monoxide increased. Table 4 listed the optimum condition and the performance of integrated reforming system. At the optimum condition, the hydrogen selectivity was $86.4 \%$ and the thermal efficiency of the system was $44.8 \%$. The product gas included $73.9 \% \mathrm{H}_{2}, 24.7 \% \mathrm{CO}_{2}$ and $1.4 \% \mathrm{CO}$ and the total volume production rate was $23.5 \mathrm{ml} / \mathrm{min}$. The amount of hydrogen can produce $1.5 \mathrm{~W}$ of power on a typical PEM fuel cell which is high enough to power typical cellular phones.

\section{CONCLUSION}

The concept of hydrogen peroxide utilization as a heat source of methanol steam reformer was proposed and realized, which enhances the system efficiency. By the design improvement of the system with the results, more compact, efficient and useful MEMS-based reformer system is almost in hand.
Table 1 Optimum operating conditions and integrated performance of the methanol reformer/hydrogen peroxide heat source

\begin{tabular}{|l|c|c|}
\hline & HPD reactor & MSR reactor \\
\hline Temperature & $278{ }^{\circ} \mathrm{C}$ & $253{ }^{\circ} \mathrm{C}$ \\
\hline Pressure & $1 \mathrm{~atm}$ & $1 \mathrm{~atm}$ \\
\hline $\mathrm{S} / \mathrm{C}$ & & 1.1 \\
\hline $\mathrm{H}_{2} \mathrm{O}_{2}$ concentration & $82 \mathrm{wt} \%$ & \\
\hline Feed flow rate & $2 \mathrm{ml} / \mathrm{h}$ & $10 \mathrm{ml} / \mathrm{h}$ \\
\hline WHSV & $0.68 \mathrm{~mol} / \mathrm{g}-\mathrm{h}$ & $6.32 \mathrm{~mol} / \mathrm{g}-\mathrm{h}$ \\
\hline Inner volume & $0.3 \mathrm{~cm}{ }^{3}$ & $0.3 \mathrm{~cm}{ }^{3}$ \\
\hline Conversion & $98.4 \%$ & $91.2 \%$ \\
\hline H $\mathrm{H}_{2}$ production rate & \multicolumn{2}{|c|}{$1.4 \%$} \\
\hline CO composition & $\begin{array}{l}\text { HPD: Hydrogen Peroxide Decomposition } \\
\text { MSR: Methanol Steam Reforming }\end{array}$ \\
\hline
\end{tabular}

\section{ACKNOWLEDGEMENT}

This research was supported by KOSEF through CERC at KAIST

\section{REFERENCE}

[1] J. D. Holladay, J. S. Wainright, E.O. Jones, S.R. Gano, "Power generation using a mesoscale fuel cell integrated with a microscale fuel processor," J. Power Sour., vol. 130, pp. 111-118, 2004

[2] A. V. Pattekar, M, V. Kothare, "A Microreactor for Hydrogen Production in Micro Fuel Cell Applications," J. Microelectromech. Syst., vol 13, no. 1, pp. 7-18, 2004

[3] B. Lindstrom, L. J. Pettersson, "Development of a methanol fuelled reformer for fuel cell applications," J. Power Sour., vol. 118, pp. 71-78, 2003

[4] M. Krumpelt, T. R. Krause, J. D. Carter, J. P. Kopasz, S. Ahmed, "Fuel processing for fuel cell systems in transportation and portable power applications," Catal. Today, vol. 77, pp. 3-16, 2002

[5] T. Kim, S. Kwon, "Design, fabrication and testing of a catalytic microreactor for hydrogen production," J. Micromech. Microeng., Vol. 16, pp. 1752-1760, 2006 